\title{
KAJ IAN PERSENTASE PENAMBAHAN GULA TERHADAP KOMPONEN MUTU SIRUP BUAH NAGA MERAH
}

\author{
Asmawati $^{i^{*}}$, Hamzan Sunardi ${ }^{2}$, Syirril Ihromi ${ }^{2}$ \\ ${ }^{1}$ Program Studi Teknologi Hasil Pertanian Faperta UM Mataram asmawatiraba@gmail.com \\ ${ }^{2}$ Program Studi Teknologi Hasil Pertanian Faperta UM Mataram
}

\section{INFO ARIIKEL}

RiwayatArtikel:

Diterima: 05 - 03- 2018

Disetujui : 18 - 07 - 2018

Kata Kunci:
buah naga merah
gula
mutu
sirup

\begin{abstract}
ABSTRAK
Abstrak:Buah naga (Dragon Fruit) merupakan tanaman musiman yang biasanya dikonsumsi dalam bentuk segar. Buah naga termasuk dalam buah yang eksotik karena penampilannya yang menarik ,rasanya asam manis menyegarkan dan memiliki beragam manfaat untuk kesehatan. Manfaat buah naga antara lain adalah sebagai anti hiperkolesterolemik, anti radikal bebas karena mengandung betasianin.Untuk meningkatkan nilai tambah dari buah naga merah ,maka dapat diolah menjadi beberapa jenis olahan,diantaranya jus, selai, es goyang, jelly dan sirup. Penelitian ini bertujuan untuk mengetahu ipengaruh persentase penambahan gulaterhadap sifat kimia dan organoleptik sirup buah naga merah.Rancangan yang digunakan dalam penelitian ini adalah Rancangan Acak Lengkap (RAL) dengan perlakuan satu factor yaitu persentase penambahan gula dalam pembuatan sirup buah naga merah gula yang terdiri dari 5 perlakuan (P1: $45 \%$, P2 : 50 \% P3 : 55 \% P4 : 60 \%, P5 : 65 \%). Masing-masing perlakuan diulang sebanyak 3 (tiga) kali sehingga diperoleh 15 unit percobaan. Data hasil pengamatan dianalisis dengan analisis keragaman (Analisis of variance) pada taraf nyata 5 \%.Bila terdapat pengaruh bedanyata dilanjutkan dengan uji Beda Nyata Jujur (BNJ) pada taraf nyata yang sama.Hasil penelitian menunjukkan bahwa Persentase penambahan gula berpengaruh secara nyata terhadap sifat kimia yaitu kadar gula reduksi, kadar air, dan sifat organoleptik rasa dan kekentalan, tetap tidak berpengaruh secara nyata terhadap sifat kimia vitamin c dan sifat organoleptik warna,dan aroma sirup buah naga merah yang diamati. Semakin tinggi persentase penambahan gula dalam pembuatan sirup buah naga merah maka kadar gula reduksi semakin tinggi sedangkan kadar air semakin menurun. Persentase penambahan gula sampai perlakuan P5 (penambahan gula $65 \%$ ) cenderung masih disukai panelis dari segi aroma, rasa dan kekentalan.
\end{abstract}

Abstract:

\section{A. PENDAHULUAN}

Buah naga (Dragon Fruit) merupakan tanaman musiman yang biasanya dikonsumsi dalam bentuk segar. (Saati, 2009). Buah naga termasuk dalam buah yang eksotik karena penampilannya yang menarik,rasanya asam manis menyegarkan dan memiliki beragam manfaat untuk kesehatan (Sutomo, 2007). Manfaat buah naga menurut (Marhazlina, 2008) adalah sebagai anti hiperkolesterolemik. Sedangkan Pedreno dan Escribano (2001) menyatakan bahwa buah naga berpotensi sebagai anti radikal bebas karena mengandung betasianin.Buah naga yang paling diminati konsumen dewasa ini adalah jenis buah naga merah (Hylocereus polyrhiruz) karena buah naga merah ini memiliki rasa lebih manis tanpa rasa langu dibanding jenis lainnya yang berwarna putih.

Menurut Kristanto (2009) buah naga kaya akan air 90,2\% dan vitamin C 9,4 mg. Sedangkan menurut Mahattanatawe et al., (2006) Zat gizi lain yang banyak terdapat dalam buah naga merah adalah kalsium 6,3 - 8,8 mg, fosfor 30,2 - 36,1 mg,Niasin 1,297 - 1,300 mg ,betakaroten 0,005 - 0,012 mg dan serat $0,7-0,9 \mathrm{mg}$.

Lim et al, (2006),mengatakan biji buah naga merah mengandung protein ,lemak, omega 3,dan fitoalbuminSalah satu keunggulan buah naga selain kandungan gizinya, juga warna merah yang dihasilkan buah naga yang menarik untuk dijadikan sirup, warna merah pada buah naga disebabkan karena mengandung senyawa betacyanin sebagai anti proliferasi dan menghambat pertumbuhan tumor. Coultate,(1996) menyatakan bahwa betalain dibagi menjadi dua kelompok yaitu betasianin dengan warna pigmen keunguan ( $\lambda \max 534-555 \mathrm{~nm}$ ) dan betaxantin dengan warna pigmen kuning ( $\lambda \max 480 \mathrm{~nm}$ ) betasianin adalah zat warna yang berfungsi memberikan warna merah dan berpotensi menjadi pewarna alami untk bahan pangan yang lebih aman bagi kesehatan dibandingkan dengan pewarna sintetik.Sirup di pasaran mempunyai warna cerah dan umumnya dibuat dengan penambahan zat pewarna.

Buah naga merah mengandung, serat yang dapat mencegah kanker usus dan memperlancar proses pencernaan (Wu et al., (2006) , betakaroten untuk kesehatan mata, menguatkan otak dan menurunkan kadar glukosa dalam darah (Raveh et al.,1998), kalsium untuk menguatkan tulang dan fosfor pertumbuhan badan (Zainoldin dan Baba, 2009), serta mengandung vitamin $\mathrm{C}$ sebagai antioksi dan yang mempunyai kemampuan memproteksi oksidasi yang disebabkan radikal bebas.

Biji buah naga mengandung antioksidan penyerang (fitoalbumin) dan omega 3, (Wu et al., 2006) yang berfungsi untuk mencegah pembentukan radikal bebas penyebab kangker, dan tidak menyebabkan kenaikan kadar kolesterol 
Kelemahan dari buah naga salah satunya adalah mudah rusak.Buah naga merah yang siap dipetik tanpa cacat fisik hanya memiliki daya simpan 10 sampai 14 hari disuhu ruang. Dengan kandungan air buah naga yang sangat tinggi mengakibatkan buah naga akan menjadi semakin lunak dan perlahan membusuk pada bagian kulit diikuti daging buah bagian dalam. Buah naga yang mengalami luka atau cacat pada bagian kulit luar akan lebih cepat terjadi pembusukan. Hal ini bisa terjadi pada saat proses pemetikan, penumpukan pada wadah saat pemetikan dan perjalanan buah naga menuju tempat penyimpanan. Proses pembusukan buah naga diawali dengan berkurangnya kadar air buah, kulit buah keriput dan ukuran buah mengecil (Mizrahi et al., 2002).

Buah naga dapat dikonsumsi dalam bentuk segar dan untuk meingkatkan nilai tambah dari buah naga merah ,maka dapat diolah menjadi beberapa jenis olahan, diantaranya jus,selai,es goyang,jelly dan sirup. Sirup buah adalah produk yang dibuat dari larutan gula kental dengan rasa dan aroma yang ditentukan oleh buah segarnya (Satuhu, 1994). Buah segar yang biasa digunakan dalam pembuatan sirup adalah buah yang mempunyai warna yang menarik, aroma yang kuat dan rasa yang khas. Buah naga mempunyai cita-rasa dan aroma yang khasdan bersifat juici dengan kadar air yang tinggi, sehingga baik untuk diolah menjadi sirup.

Menurut SNI No. 01-3544-1994, sirup didefinisikan sebagai larutan gula pekat (Sakarosa: high fructose syrup dan atau gula inversi lainnya) dengan atau tanpa penambahan bahan tambahan makanan yang diijikan. Definisi sirup yang lain yaitu sejenis minuman ringan berupa larutan kental dengan cita rasa beraneka ragam, biasanya mempunyai kandungan gula minimal 65\%.

Prinsip pembuatan sirup adalah pasteurisasi. Pasteurisasi adalah proses pemanasan dengan menggunakan suhu dibawah $100^{\circ} \mathrm{C}$ untuk menginaktifkan mikroba berbahaya agar memiliki daya tahan lebih lama(Rosenau, 1913). Sebelum proses pasteurisasi dilakukan sari buah didapat dari penghancuran buah menjadi bubur buah, lalu diperas dandisaring untuk mendapatkan sari buah, setelah itu ditambahkan gula sebagai pemanis sekaligus sebagai bahan pengawet, lalu dimasukkan ke dalam botol, barulah dilakukan pasteurisasi agar memiliki daya tahan lebih lama. Dalam penelitian ini, bahan tambahan yang digunakan adalah gula sebagai pemanis. Hal ini dilakukan karena gula mudah larut dalam air, dimana semakin tinggi suhu maka tingkat kelarutan akan semakin besar. Gula pasir mempunyai rasa manis yang lebih enak dan tidak berlebihan serta memiliki fungsi sebagai bahan pengawet. Selain itu gula pasir lebih ekonomis dan mudah didapat serta berperan dalam memperbaiki cita rasa dan aroma dengan cara membentuk keseimbangan antara rasa asam, rasa pahit dan rasa asin.
Menurut Hadiwijaya et al. (2013 ) prosespembuatan sirup buah naga yang paling disukai panelis adalah dengan penambahan gula sebesar 55\% dari berat bahan.

\section{B. METODE PENELITIAN}

\section{Metode Penelitian}

Metode yang digunakan dalam penelitian ini adalah Metode Eksprimental dengan percobaan di Laboraturium.

\section{Rancangan Penelitian.}

Rancangan yang digunakan dalam penelitian ini adalah Rancangan Acak Lengkap (RAL) dengan perlakuan satu faktor yaitu persentase penambahan dalam pembuatan sirup buah naga merahgula yang terdiri dari 5 perlakuan sebagai berikut :

T1:Persentase penambahan gula $45 \%$ dari berat saribuah

T2 :Persentase penambahan gula $50 \%$ dari berat saribuah

T3 :Persentasepenambahangula $55 \%$ dari berat saribuah

T4 :Persentase penambahan gula $60 \%$ dari berat saribuah

T5 :Persentase penambahan gula $65 \%$ dari berat saribuah

Setiap perlakuan membutuhkan berat sampel (sari buah naga $300 \mathrm{ml}$ ), masing-masing perlakuan diulang sebanyak 3 (tiga) kali sehingga diperoleh 15 unit percobaan. Data hasil pengamatan akan dianalisis dengan analisis keragaman (Analisis of variance) pada taraf nyata $5 \%$. Bila terdapat pengaruh beda nyata dilanjutkan dengan uji Beda Nyata Jujur (BNJ) pada taraf nyata yang sama (Hanafiah, 2002).

\section{Tempat dan Waktu Penelitian.}

Penelitian ini telah dilaksanakan di Laboratorium Program studi Teknologi Hasil Pertanian Fakultas Pertanian Universitas Muhammadiyah Mataram pada bulan Juni sampai Juli 2016 yaitu pembuatan produk sirup buah naga merah dan uji sifat organoleptik, (warna, aroma, rasa dan kekentalan), dan uji sifat kimia (kadar air dan kadar vitamin c ), sedangkan untuk analisis kadar gula reduksi dilaksanakan di Laboratorium Kimia Analitik (MIPA) Universitas Mataram pada bulan Juni 2016 .

\section{Bahan dan Alat Penelitian Bahan penelitian}

Bahan-bahan yang digunakan dalam penelitian ini antara lain : Buah naga berdanging merah, gula pasir, air bersih,asam sitrat,aquadest, $\mathrm{Pb}$ asetat, Reagensia Nelson, Reagensia Arsenomolibdat, Iodium 0,01 N, larutan Amilum $1 \%$.

\section{Alat Penelitian}

Alat-alat yang digunakan dalam penelitian ini adalah timbangan analitik, botol timbang, oven, erlemenyer, kertas saring, blender, gelas piala, buret, pipet, botol kaca, sendok teh, cangkir, pisau stainless stell, talenan, kain saring, baskom, labu ukur, kompor, tabung reaksi. 


\section{Pelaksanaan Penelitian}

Adapun beberapaa tahapan proses pembuatan sirup buah naga sesuai denganmodifikasi Hadiwijaya .et al, (2013),sebagai berikut :

a. Persiapan bahan dan alat.

Bahan yang digunakan adalah buah naga merah,air, gula dan bahan tambahan asam sitrat.Alat yang digunakan adalah timbangan, panci, kompor, gelas ukur, pengaduk kayu, corong, botol dan tutup botol. Sebelum dipakai, botol dan tutup botol ini harus disterilisasi terlebih dahulu. Caranya botol dicuci dengan deterjen lalu dibilas menggunakan air bersih, kemudian dilakukan perebusan dalam air sampai mendidih selama 30 menit.Botol yang digunakan adalah botol kaca yang mempunyai tutup yang bisa dieratkan.

\section{b. Proses Pembuatan Sirup Buah Naga Merah}

Secara garis besar, Diagram alir proses pembuatan sirup buah naga dilakukan dengan cara modifikasi Hadiwijaya.et al,(2013) sebagai berikut :

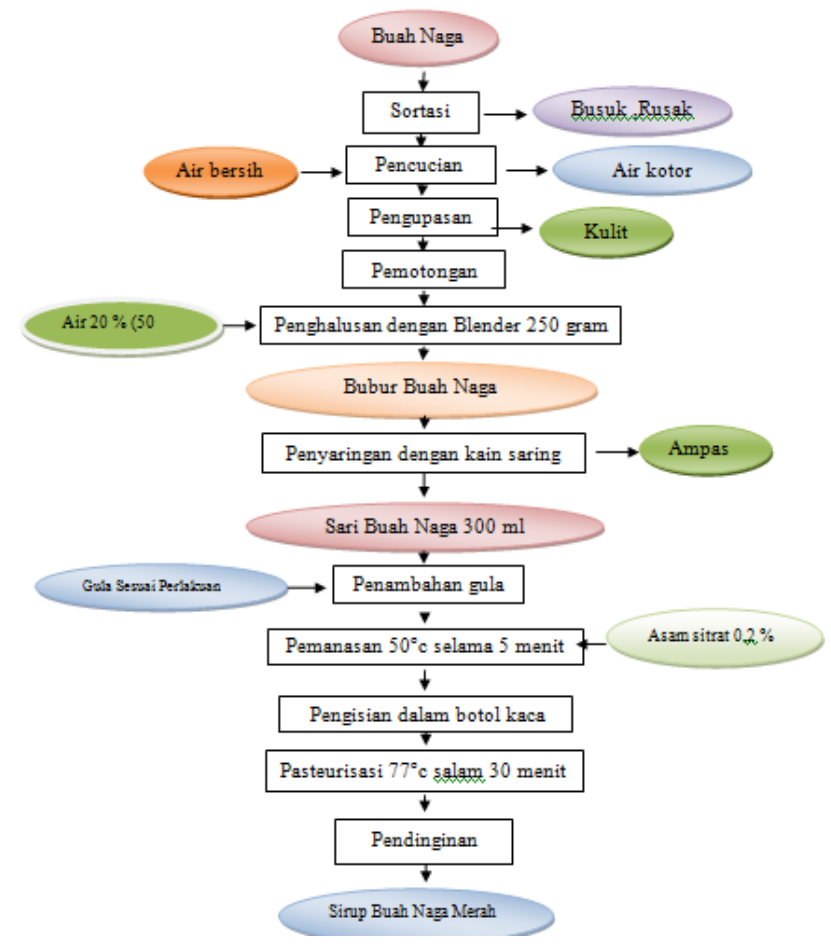

Gambar 1: Diagram alir pembuatan sirup buah naga merah modifikasi (Hadiwijaya, et al., 2013)

\section{Parameter dan Cara Pengamatan}

\section{Parameter yang diamati}

Parameter yang diamati dalam penelitian ini meliputi :sifat kimia (kadar air,kadar gula reduksi dan kadar vitamin c ), sedangkan sifat organoleptik, (warna, aroma, rasa dan visikositas).

\section{Cara pengamatan parameter}

1. Kadar gula reduksi
Penentuan kadar gula reduksi dilakukan dengan spektrometri metode Nelson Somogy (Sudarmadji, et al, 1997). Prosedur kerjanya sebagai berikut :

a). Penyiapan kurva standar

1. Dibuat larutan glukosa standar (100 mg/100 ml).

2. Dari larutan glukosa standar tersebut dilakukan 5 kali pengenceran sehingga diperoleh larutan glukosa dengan kosentrasi 2, 4, 6, 8, dan $10 \mathrm{mg} / 100 \mathrm{ml}$.

3. Disiapkan 6 tabung reaksi yang bersih.Masing- masing tabung diisi dengan $1 \mathrm{ml}$ larutan glukosa standar tersebut.Satu buah -tabung reaksi diisi dengan $1 \mathrm{ml}$ aquadest sebagai blanko.

4. Ditambahkan ke dalam masing-masing tabung tersebut $1 \mathrm{ml}$ Reagensia Nelson dan dipanaskan semua tabung pada air mendidih selama 20 menit.

5. Diambil semua tabung dan segera bersama-sama dengan yang berisi aquadest didinginkan sampai suhu $25^{\circ} \mathrm{C}$.

6. Setelah dingin ditambah $1 \mathrm{ml}$ reagenesia Arsenomolibdat dikocok sampai semua endapan $\mathrm{Cu}_{2} \mathrm{O}$ yang ada larut kembali.

7. Setelah endapan larut sempurna, ditambah $7 \mathrm{ml}$ aquadest, digojok sampai homogen.

8. Ditera Optical Density “OD” masing-masing larutan tersebut pada panjang gelombang $540 \mathrm{~nm}$.

b).Penentuan gula reduksi pada contoh

1. Disiapkan larutan contoh yang mempunyai kadar gula reduksi sekitar 2-8 mg/100 ml. Perlu diperhatikan larutan contoh ini harus jernih, karena itu bila dijumpai larutan contoh yang keruh atau bewarna perlu dilakukan penjernihan dengan penambahan $\mathrm{Pb}$ asetat.

2. Dipipet $1 \mathrm{ml}$ larutan contoh yang jernih tersebut ke dalam tabung reaksi yang bersih.

3. Ditambah $1 \mathrm{ml}$ reagensia Nelson dan selanjutnya diperlukan sama dengan penyiapan kurva standar di atas.

4. Kadar gula reduksi dapat ditentukan berdasarkan nilai OD larutan contoh dan kurva standar larutan glukosa standar.

Perhitungan : $\mathrm{Y}=\mathrm{a}+\mathrm{bX}$

Kadar gula reduksi $(\%)=\frac{\mathrm{X} \times \mathrm{FP}}{\mathrm{g} \text { bahan }}$

Keterangan : $\mathrm{Y}=$ Nilai absorbansi $\quad \mathrm{X}=$ Nilai gula reduksi

a dan $\mathrm{b}=$ Konstanta regresi $\mathrm{FP}=$ Faktor pengenceran Kadar Air

Penentuan kadar air dengan menggunakan metode pemanasan dengan oven (Sudarmadji, et al., 1997), dengan prosedur sebagai berikut :

a. Bahan yang telah dihaluskan, sebanyak 2 gram dimasukkan ke dalam botol timbang yang sudah diketahui beratnya.

b. Dikeringkan dalam oven pada suhu $100^{\circ} \mathrm{C}$ selama. 3 jam

c. Setelah itu didinginkan dalam desikator dan timbang. 
d. Dilakukan pengeringan kembali selama 30 menit, didinginkan dalam desikator dan ditimbang. Perlakuan ini diulang sampai tercapai berat konstan, dimana selisih penimbangan berturut — turut kurang dari 0,2 mg.

Perhitungan :

\section{Vitamin C}

$$
\text { kadar air }=\frac{\text { berat awal }- \text { berat akhir }}{\text { berat awal }} \times 100 \%
$$

Penentuan kadar vitamin C dengan menggunakan metode titrasi iodium (Sudarmadji, et al., 1997), dengan prosedur sebagai berikut :

a. Ditimbang kurang lebih $25 \mathrm{ml}$ sampel

b. Catat sebagai berat mula-mula

c. Diencerkan dengan aquades didalam labu ukur $100 \mathrm{ml}$ hingga tera

d. Dipipet $10 \mathrm{ml}$ sampel, kemudian dimasukkan ke dalam Erlenmeyer 250ml

e. Ditambahkan 2 tetes larutan amilum

f. Sampel dititrasi dengan larutan $I_{2}$ sampai berubah warna menjadi biru violet

g. Catat volume $\mathrm{I}_{2}$ yang digunakan

$$
\begin{aligned}
& \text { vit } \mathrm{c}\left(\frac{\mathrm{mg}}{100} \mathrm{~g} \text { bahan }\right) \\
& =\frac{\text { ml yodium } \times 0,88 \times f p}{g \text { bahan }} \times 100 \%
\end{aligned}
$$

Penilaian Sifat Organoleptik.

Pengamatan warna, tekstur, rasa dan aroma dilakukan secara organoleptik dengan metode Hedonik Scale (Rahayu, 2008) sebagai berikut:

Pengamatan terhadap aroma sirup skala penilitian sebagai berikut:
a. Sangat tidak suka
b. Tidak suka
C. Agak suka
d. Suka
e. Sangat suka.

Pengamatan terhadap warna Sirup dengan Skala penilian sebagai berikut :
a. Merah
b. Agak merah
c. Pink
d. Pink muda
e. Pink muda sekali

Pengamatan terhadap visikositas Sirup menggunakan peneliaian sebagai berikut :
a. Sangat Encer
b. Encer
c. Agak Kental
d. Kental

\section{e. Sangat Kental}

Pengamatan terhadap rasa sirup menggunakan peneliaian sebagai berikut :
a. Sangat tidak enak

b. Tidak enak
c. Agak enak
d. Enak
e. Sangat enak

\section{HASIL DAN PEMBAHASAN}

Hasil dan analisis hasil pengamatan yang dihasilkan pada penelitian ini tertera pada Tabel 1 sampai Tabel 4 sebagai berikut :

Tabel 1.Siginifikansi pengaruh penambahan gula terhadap sifat kimia sirup buah naga merah.

\begin{tabular}{|l|c|c|c|}
\hline \multicolumn{1}{|c|}{ Parameter } & F Hitung & F Tabel & Keterangan \\
\hline Kadar Gula Reduksi & 89,141 & 3,48 & $\mathrm{~S}$ \\
\hline Kadar Air & 8424.935 & 3,48 & $\mathrm{~S}$ \\
\hline Kadar Vitamin C & 1,167 & 3,48 & NS \\
\hline
\end{tabular}

Keterangan :S = Signifikan

$$
\text { NS = Non Signifikan }
$$

Pada Tabel 1 di atas menunjukan bahwa persentase penambahan gula dalam pembuatan sirup buah naga merah berpengaruh secara nyata terhadap kadar gula reduksi dan kadar air sehingga dilakukan uji lanjut BNJ pada taraf 5\%, sedangkankadar vitamin C nya tidak berpengaruh secara nyata sehingga tidak dilakukan uji lanjut BNJ pada taraf 5\%.

Purata hasil analisis pengaruh penamabahan gula terhadap sifat kimia sirup buah naga merah dapat dilihat pada Tabel 2 berikut :

Tabel 2. Purata hasil analisis pengaruh penambahan gula terhada sifat kimia sirup buah naga merah

\begin{tabular}{|c|c|c|c|}
\hline \multirow{2}{*}{ Perlakuan } & \multicolumn{3}{|c|}{ Parameter sifat kimia } \\
& $\begin{array}{c}\text { Kadar gula reduksi } \\
(1)\end{array}$ & $\begin{array}{c}\text { Kadar air } \\
(2)\end{array}$ & $\begin{array}{c}\text { Kadar } \\
\text { vitamin C } \\
(3)\end{array}$ \\
\hline - P1 45\% & $10,21 \mathrm{a}$ & $80,40 \mathrm{e}$ & 1,76 \\
- P2 50\% & $14,18 \mathrm{~b}$ & $78,19 \mathrm{~d}$ & 1,76 \\
- P3 55\% & $15,14 \mathrm{c}$ & $75,15 \mathrm{c}$ & 1,64 \\
- P4 60\% & $16,24 \mathrm{~d}$ & $73,20 \mathrm{~b}$ & 1,64 \\
- P5 65\% & $19,12 \mathrm{e}$ & $70,12 \mathrm{a}$ & 1,52 \\
\hline BNJ 5 \% & 0,505 & 0,205 & - \\
\hline
\end{tabular}

Keterangan :Angka - angka yang diikuti oleh huruf yang sama pada kolom yang sama tidak berbeda nyata pada taraf $5 \%$.

Signifikansi pengaruh penamabahan gula terhadap sifat organoleptik sirup buah naga merah dapat dilihat pada Tabel 3 berikut : 
Tabel 3.Siginifikansi pengaruh penambahan gula terhadap sifat organoleptik sirup buah naga merah.

\begin{tabular}{|l|l|c|c|}
\hline \multicolumn{1}{|c|}{ Parameter } & F Hitung & F Tabel & Keterangan \\
\hline -Wama & 1,283 & 2,536 & NS \\
\hline -Aroma & 0,289 & 2,536 & NS \\
\hline - Rasa & 3.614 & 2,536 & S \\
\hline -Kekentalan & 18.673 & 2,536 & S \\
\hline
\end{tabular}

Keterangan : NS = Non Signifikan

$$
\mathrm{S}=\text { Signifikan }
$$

Pada Tabel 3 di atas menunjukan bahwa pengaruh penambahan gula dalam pembuatan sirup buah naga merah berpengaruh secara nyata (signifikan) terhadap sifat organoleptik (rasa dan kekentalan) sehingga harus dilakukan uji lanjut BNJ pada taraf 5\%, yang dapat dilihat pada Tabel 4 sedangkan terhadap sifat organoleptik (warna, aroma,) tidak signifikan sehingga tidak dilakukan uji lanjut BNJ pada taraf 5\%.

Tabel 4. Purata hasil analisis pengaruh penambahan gula terhadap sifat organoleptik sirup buah naga merah.

Keterangan : Angka - angka yang diikuti oleh huruf yang

\begin{tabular}{|c|c|c|c|c|}
\hline \multirow[t]{2}{*}{ Perlakuan } & \multicolumn{4}{|c|}{ Parameter sifat organoleptik } \\
\hline & Warna (l) & $\begin{array}{c}\text { Aroma } \\
(2)\end{array}$ & $\begin{array}{c}\text { Rasa } \\
(3) \\
\end{array}$ & $\begin{array}{c}\text { Kekentalan } \\
(4)\end{array}$ \\
\hline P1 45\% & 3,800 & 3,867 & $3,800 \mathrm{a}$ & $2.467 \mathrm{a}$ \\
\hline $\mathrm{P} 250 \%$ & 3,800 & 3,933 & $3,933 \mathrm{ab}$ & $2,933 \mathrm{a}$ \\
\hline P3 55\% & 3,467 & 4,067 & $4,000 \mathrm{ab}$ & $3,000 \mathrm{a}$ \\
\hline $\mathrm{P} 460 \%$ & 3,400 & 4,067 & $4,333 \mathrm{ab}$ & $3.533 \mathrm{a}$ \\
\hline P5 65\% & 3,267 & 4,067 & $4,667 b$ & $4,267 \mathrm{~b}$ \\
\hline BNJ $5 \%$ & - & - & 0,736 & 0,635 \\
\hline
\end{tabular}

tidakberbeda nyata pada taraf 5\%.

\section{Pembahasan}

Berdasarkan hasil dan analisis hasil yang terbatas pada ruang lingkup penelitian ini maka dapat dikemukakan pembahasan sebagai berikut

\section{Sifat Kimia Sirup Buah Naga Merah}

\section{a. Kadar Gula Reduksi}

Pada Tabel 2 kolom pertama (kadar gula reduksi) menunjukkan bahwa semakin tinggi persentase penambahan gula ,maka kadar gula reduksi dalam sirup buah naga merah semakin tinggi. Kadar gula reduksi tertinggi diperoleh perlakuan P5 (penambahan gula 65\%) yaitu sebesar 19,12\%, dan kadar gula reduksi sirup buah naga merah terendah diperoleh pada perlakuan P1 (penambahan gula 45\%) yaitu sebesar 10,21\%. Hubungan pengaruh Persentase penambahan gula terhadap kadar gula reduksi sirup buah naga merah dapat dilihat pada Gambar 2 berikut :

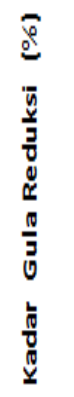

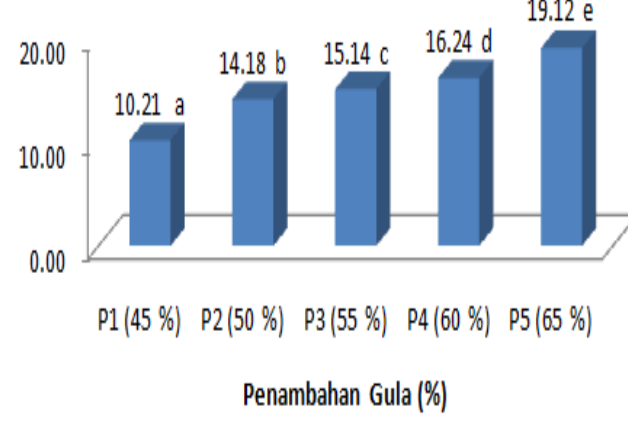

Gambar 2. Grafik pengaruh Persentase penambahan gula terhadap kadar gula reduksi sirup buah naga merah.

Tingginya kandungan gula reduksi pada perlakuan P5 yaitu sebesar 19,12 \% disebabkan karena pada perlakuan ini penambahan gulanya tinggi yaitu 195 g kedalam $300 \mathrm{ml}$ sari buah naga merah. Sehingga menyebabkan kadar gula reduksi dalam sirup buah naga merah akan semakin meningkat.

Semakin tinggi konsentrasi gula yang ditambah maka semakin tinggi kadar gula reduksi yang diperoleh. Kenaikan kadar gula reduksi disebabkan karena adanya proses inverse sukrosa menjadi gula reduksi dan proses inversi ini meningkat sejalan dengan meningkatnya kandungan sukrosa tersebut, disamping itu selama pemanasan terjadi proses hidrolisis sukrosa menjadi gula reduksi (glukosa dan fruktosa). Hal ini didukung oleh pernyataan Buckle, dkk (1987) yang menyatakan bahwa gula mempunyai daya larut yang tinggi, sehingga cepat hidrolisis menjadi monosakarida. Selanjutnya Apandi (1984) menyatakan bahwa gula pasir (sukrosa) yang larut dalam air dan dipanaskan, sebagai sukrosa akan terurai menjadi glukosa dan fruktosa yang disebut gula invert. Hidrolisis tersebut biasanya disebut dengan proses inverse yang terjadi pada suasana asam (Winarno, 1989).

\section{b. Kadar Air}

Pada Tabel 2 kolom kedua (kadar air) menunjukkan bahwa semakin tinggi rasio penambahan gula ,maka kadar air dalam sirup buah naga merah semakin rendah dan memberikan pengaruh secara nyata pada taraf nyata 5\%.Kadar air tertinggi diperoleh pada perlakuan P1 (45\% penambahan gula) yaitu sebesar $80,40 \%$ dan kadar air terendah di peroleh pada perlakuan P5 (65\% penambahan gula) yaitu sebesar 70,12 \%.Hubungan pengaruh persentase penambahan gula terhadap kadar air sirup buah naga merah dapat dilihat pada Gambar 3 berikut : 
Jurnal AGROTEK Vol. 5 No.2, 2018 / Kajian Persentase Penambahan Gula Terhadap Komponen Mutu Sirup Buah Naga Merah/ Asmawati , Hamzan Sunardi , Syirril Ihromi.

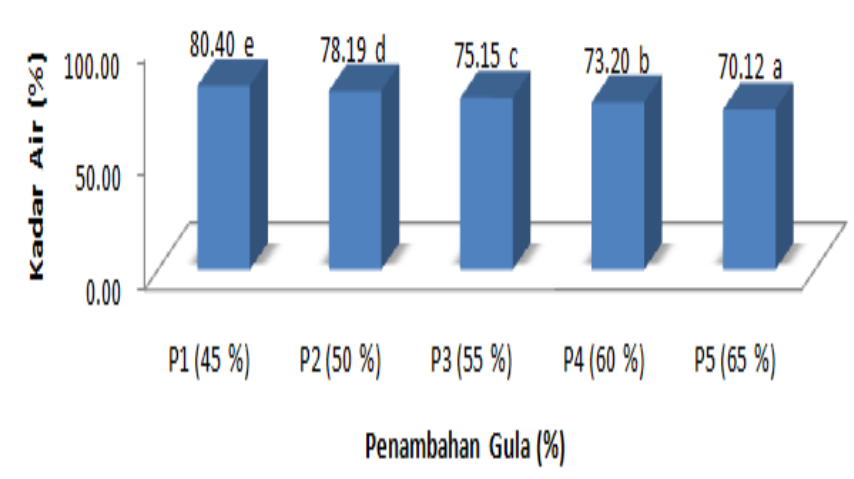

Gambar 3. Garafik pengaru penambahan gula terhadap kadar air sirup buah naga merah

Rendahnya kadar air yang diperoleh Pada perlakuan P5 (penamabahan gula 65\%) sebesar 70,12 \%, disebabkan karena persentase penambahaan gulanya tertinggi. Semakin tinggi gula yang ditambahkan pada sirup buah naga maka nilai kadar air sirup buah naga merah semakin rendah, Hal ini disebabkan karena sifat gula yang menyerap air (hidrofilik) dan dilakukan proses pemanasan, sehingga pada saat pemanasan terjadi proses penguapan air menyebabkan kadar air menjadi berkurang.Hal ini dikarenakan pada proses perebusan menggunakan suhu $50^{\circ}-80^{\circ} \mathrm{C}$, air sedikit demi sedikit akan menguap karena rentan dengan panas

\section{c. Kadar Vitamin C}

Pada Tabel 2 kolom ketiga (kadar vitamin C ) menunjukkan bahwa rasio penambahan gula tidak berpengaruh secara nyata pada taraf 5\%, Kadar vitamin C tertinggi diperoleh pada perlakuan P1 (45\% penambahan gula) dan P2 (50\% penambahan gula) yaitu sebesar 1,76 , dan terendah pada perlakuan P5 (65\% penambahan gula) yaitu sebesar 1,52 \%. Hubungan pengaruh persentase penamabahan gula terhadap kadar vitamin C sirup buah naga merah, dapat dilihat pada Gambar 3 berikut :

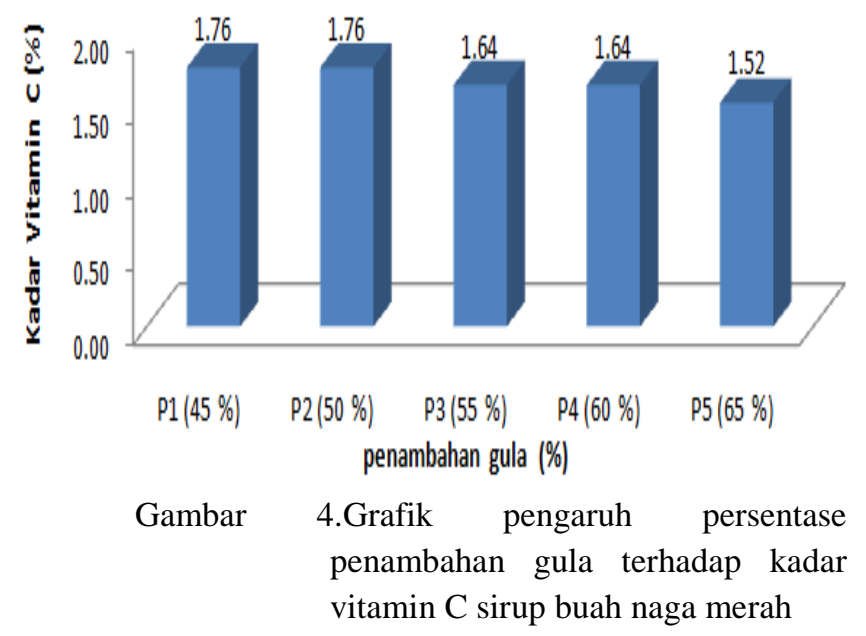

Tingginya kandungan vitamin C pada perlakuan perlakuan P1 (45\% penambahan gula) dan P2 (50\% penambahan gula) yaitu sebesar 1,76 hal ini disebabkan karenaketidakstabilan dari vitamin C dikarenakan pada proses pemanasan dan pasteurisasi, seperti yang kita ketahui vitamin $\mathrm{C}$ sangat rentan dengan pemanasan dan sangat larut dalam air, hal ini sesuai dengan pendapatWinarno (1997), yang mengantakan bahwa vitamin C merupakan vitamin yang paling mudah rusak dibandingkan dengan jenis vitamin lainnya. Disamping sangat larut dalam air, vitamin C mudah teroksidasi dan proses tersebut dipercepat oleh panas, sinar, alkali, enzim, dan oksidator lainnya. Oleh sebab itu, kandungan vitamin C yang terdapat dalam sirup buah naga merah tidak menutup kemungkinan akan mengalami penurunan ketika telah diolah menjadi sirup buah naga merah diakibatkan oleh rusaknya vitamin C oleh proses pengolahan.Semakin banyak suatu bahan pangan melalui proses pengolahan, maka akan berkurang nilai gizi atau vitamin yang terdapat dalam bahan tersebut. Selain itu penurunan kadar vitamin C pada sirup buah naga merah dikarenakan vitamin $C$ yang sangat larut air ketika penambahan gula semakin tinggi maka vitamin c yang sudah terlarut dalam air akan terikat oleh gula sehingga pada saat proses pemanasan terjadi penguapan dan kehilangan vitamin $\mathrm{C}$.

\section{Sifat Organoleptik}

\section{a. Warna}

Faktor - faktor yang menentukan mutu bahan makanan diantaranya adalah warna,cita rasa,aroma,dan kandungan gizinya. Faktor warna sangatlah berpengaruh terhadap mutu dari suatu bahan pangan, karena warna dapa dilihat langsung secara visual, sehingga secara langsung faktor warna dapat menarik perhatian konsumen, suatu produk pangan yang dinilai bergizi dan enak rasanya tidak akan dapat meningkatkan minat konsumen jika warna dan produk pangan tersebut tidak sedap di pandang mata atau memberi kesan telah menyimpang dari warna yang sebenarnya (Winarno, 2004).

Pada Tabel 4 kolom 1 (nilai warna)menunjukkan bahwa skor nilai warna sirup buah naga merah,dengan menggunakan uji hedonik (kesukaan) pada 5 (lima) perlakuan cenderung menurun.yang walaupun secara statistic tidak menunjukkan adanya pengaruh beda nyata antar perlakuan yang diamati. Hubungan pengaruh persentase penambahan gula terhadap warna sirup buah naga merah dapat dilihat pada Gambar 5.

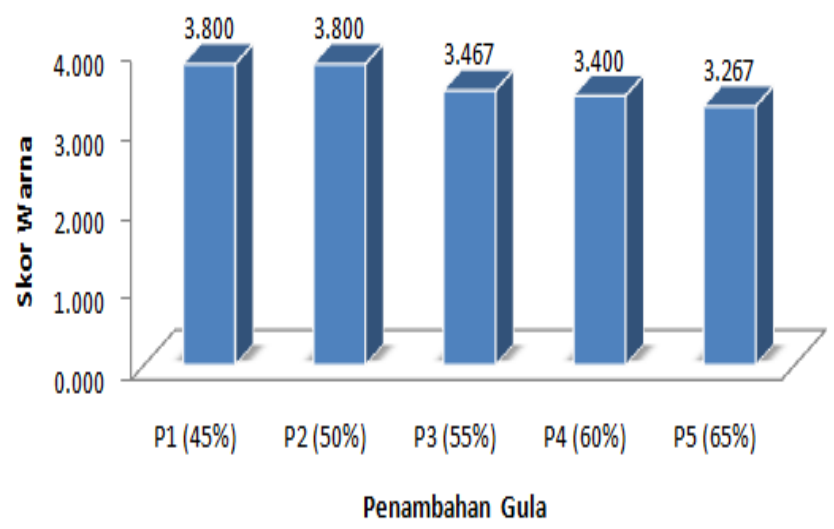

Gambar 5.Grafik pengaruh persentase penambahan gula terhadap skor nilai warna sirup buah naga merah. 
Pada Gambar 5 di atas menunjukkan bahwa skor nilai warna tertinggi diperoleh pada perlakuan P1 (penambahan gula 45\%) dan P2 (penambahan gula 50\%) yaitu sebesar $(3,800)$ dengan kriteria mendekati pink mudadan disukai oleh panelis.Hal ini dikarenakan oleh gula yang digunakan tidak terlalu berpengaruh besar terhadap warna alami dari buah naga merah dan pengolahan yang dilakukan tidak terlalu lama dengan perlakuan suhu yang rendah.

Skor nilai warna terendah didapatkan pada perlakuan P5(penambahan gula 65\%) yaitu sebesar $(3,267)$ dengan kriteria pink hal ini di sebabkan proses pengentalan dan melarutnya gula yang menyebabkab warna kurang menarik. Menurut (Nasution dkk, 2006) mengatakan bahwadaya tarik suatu jenis makanan dipengaruhi oleh warna dan merupakan bagian yang tidak terpisahkan dalam mutu produk.

\section{b. Aroma}

Pada Tabel 4 kolom 2 (nilai aroma) menunjukkan bahwa grafik hubungan persentase penamabahan gula terhadap skor nilai aroma sirup buah naga merah cenderung mengalami peningkatan dan hasil penilaian panelis lebih banyak menyukai aroma sirup buah naga merah yang semakin banyak persentase penambahan gulanya yang walaupun secara statistic yang menyebabkan adanya pengaruh beda nyata antar perlakuan yang diamati. Adapun grafik hubungan pengaruh persentase penambahan gula terhadap skor warna sirup buah naga merah dapat dilihat pada Gambar 6 berikut :

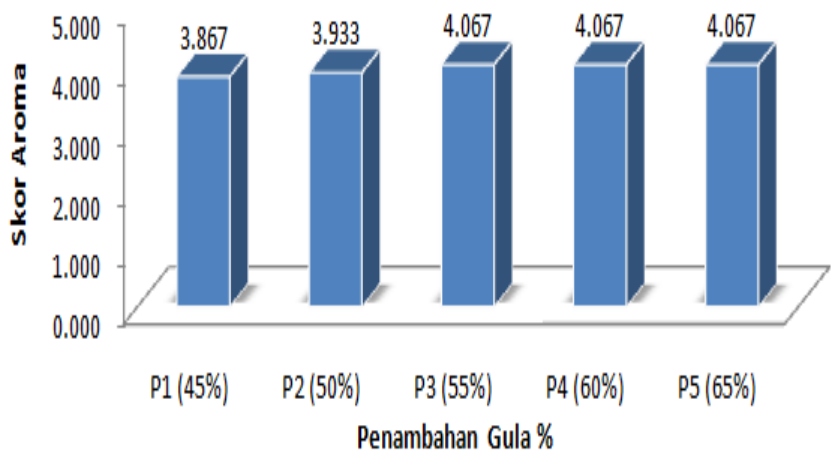

Gambar 6. Grafik pengaruh penambahan gula terhadap skor nilai aroma sirup buah naga merah.

Skor nilai aroma sirup buah naga merah tertinggi cenderung diperoleh pada perlakuan P5 (penambahan gula $65 \%$ ) ,perlakuan P4 (penambahan gula 60\%) dan perlakuan P3 (penambahan gula 55\%) dengan skor 4,067 dengan kriteriasuka,dan skor nilai terendah diperoleh pada perlakuan P1 (penambahan gula 45\%) 3,867 kriteria mendekati suka.Tingginya tingkat kesukaan panelis terhadap perlakuan P5,disebakan karena pada perlakuan P5 persentase penambahan gula paling tinggi yaitu $195 \mathrm{~g}$ dalam $300 \mathrm{ml}$ sari buah yang sudah ditambahkan air sehingga menyebabkan aroma dasarnya semakin berkurang dan aroma dari gula yang menonjol.

Penambahan gula cenderung mempengaruhi skor nilai aroma sirup buah naga merah yang diuji, Aroma yang khas dirasakan oleh indra penciuman tergantung kepada bahan penyusun dan bahan yang ditambahkan dalam makanan tersebut (Rahman,2005). Sedangkan menurut Winarno (1997) menyatakan bahwa bau makanan banyak menentukan kelezatan makanan serta cita rasa bahan pangan itu sendiri yang terdiri dari tiga komponen yaitu bau, rasa, dan rangsangan mulut

\section{d. Rasa}

Umumnya bahan pangan atau produk pangan tidak hanya terdiri dari satu rasa,tetapi merupakan gabungan dari berbagai macam rasa secara terpadu sehingga menimbulkan cita rasa yang utuh (Winarno,2004). Pada Tabel 9 kolom ketiga, menunjukkan skor nilai rasa sirup buah naga merahmengalami peningkatan sejalan dengan semakin tingginya penambahan gula pada setiap perlakuan. Hasil penilaian terhadap rasa sirup buah naga merah lebih bersifat relatif untuk masing masing panelis dan umumnya menyukai sirup buah naga merah yang manis yang menggunakan konsentrasi gula yang tinggi. Adapun Garfik hubungan pengaruh persentase penambahan gula terhadap skor nilai rasa sirup buah naga merah dapat dilihat pada Gambar 7 berikut :

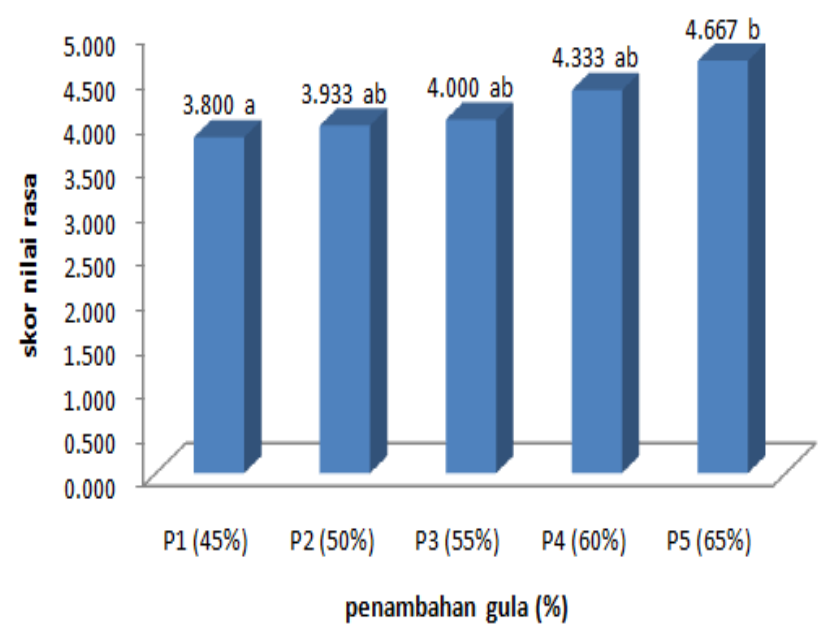

Gambar 7. Grafik pengaruh persentase penambahan gula terhadap skor nilai rasa sirup buah naga merah

Rasa merupakan faktor yang cukup penting diantara faktor - faktor lain yang berhubungan dengan organoleptik serta mutu dari produk pangan. Rasa biasanya terdiri dari komponen yang terdapat dalam bahan baku atau pembuatan atau dari bahan yang sengaja ditambahkan untuk meningkatkan kualitas dari produk pangan tersebut. Nilai rasa tertinggi cenderung diperoleh pada perlakuan P5 (penambahan gula 65\%) sebesar 4,667 dengan kriteria mendekatisangat enak dan skor nilai rasa terendah ditunjukkan pada perlakuan P1 (penambahan gula 45\%) dengan skor 3,800 dengan kriteria mendekati enak.Hal ini disebabkan karena pada perlakuan P5 penambahan gulanya lebih tinggi yaitu $65 \%$ dari berat bahan sehingga menghasilkan rasa yang manis dan disukai oleh panelis.

Menurut Winarno (1997), rasa dipengaruhi oleh beberapa faktor yaitu senyawa kimia, suhu, konsentrasi dan interaksi dengan komponen rasa yang lain. Senyawa-senyawa citarasa pada produk dapat memberikan rangsangan pada 
indera penerima saat mengkonsumsi. Namun seiring dengan meningkatnya jumlah gula yang diberikan pada masing-masing perlakuan menyebabkan semakin manisnya rasa sirup dan semakin disukai oleh panelis.

\section{e. Kekentalan}

Kekentalan adalah segi penting mutu minuman juga merupakan salah satu parameter yang penting. Pada Tabel 4 kolom empat menunjukkan skor nilai kekentalan sirup buah naga merah mengalami peningkatan sejalan dengan semakin tingginya persentase penamabahan gula. Adapun grafik hubungan pengaruh persentase penambahan gula terhadap skor nilai warna sirup buah naga merah dapat dilihat pada gambar 8 berikut :

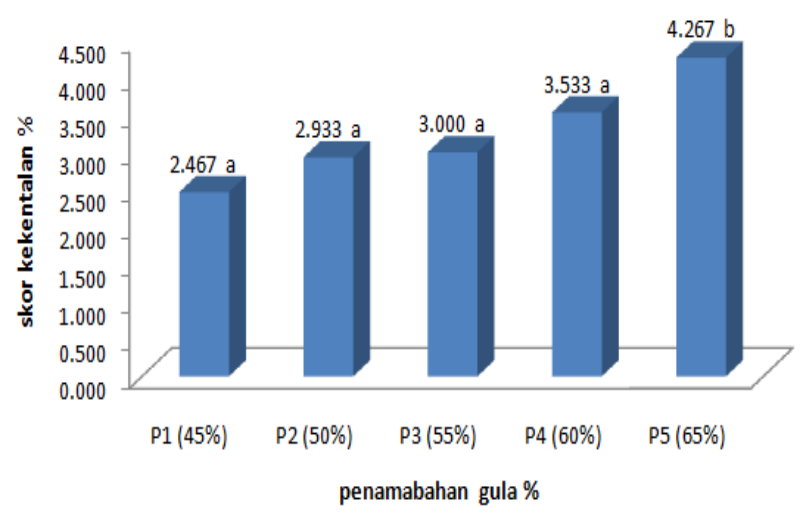

Gambar 8.Grafik pengaruh persentase penambahan gula terhadap skor nilai kekentalan sirup buah naga merah.

Nilai kekentalan tertinggi cenderung dipeoleh perlakuan P5 (penamabahan gula 65\%) yaitu sebesar 4.267 dengan kriteria kental dan skor nilai kekentalan terendah ditujukkan oleh perlakuan P1 (penambahan gula 45\%) dengan skor 2,467 dengan kriteriatidak encer.Hasil sidik ragam menunjukkan bahwa skor nilai kekentalan berbeda nyata pada berbagai perlakuan penambahan gula yang diamati. Hal ini disebabkan karena penambahan gula kedalam sari buah naga merah menyebabkan tingkat kekentalan semakin meningkat dan disukai oleh panelis.Hadiwijaya .et al, (2013) menyebutkan bahwa Penambahan gula yang semakin meningkat mempengaruhi tingkat kekentalan pada masingmasing perlakuan.

\section{SIMPULAN DAN SARAN}

\section{Simpulan}

Berdasakan hasil penelitian dan pembahasan dapat disimpulkan hal - hal berikut:

a. Persentase penambahan gula berpengaruh secara nyata terhadap beberapa komponen mutu yaitu sifat kimia kadar gula reduksi, kadar air,dan sifat organoleptik rasa dan kekentalan, tetapi tidak berpengaruh nyata terhadap sifat kimia vitamin c dan sifat organoleptik warna,dan aroma sirup buah naga merah yang diamati.

b. Semakin tinggi penambahn gula dalam pembuatan sirup buah naga merah maka kadar gula reduksi semakin tinggi sedangkan kadar air semakin
menurun.Kadar air tertinggi diperoleh perlakuan P1 = penambahan gula $45 \%$ dari berat sari buah $(80,40 \%)$ sedangkan kadar gula reduksi tertinggi diperoleh pada perlakuan P5 = penambahan gula sebesar 65\% (19,12\%).

c. Semakin tinggi presentase penambahan gula maka skor nilai organoleptiknya cenderung makin disukai pada perlakuan P5 warna dengan kriteria warna pink,rasa, dan aroma dengan kriteria suka dan kekentalan dengan kriteria kental.

d. Persentase bahwa penambahan gula sampai dengan perlakuan P5 (penambahan gula 65 \%) masih disukai panelis dari segi aroma, rasa dan kekentalan.

\section{Saran}

Berdasakan hasil penelitian yang dilakukan maka dapat dikemukakan saran sebagai berikut :

a. Untuk mendapatkan sirup buah naga merah yang disukai panelis disarankan dapat menambahkan sampai dengan perlakuan P5 (penambahan gula $65 \%$ ).

b. Untuk penelitian yang lebih lanjut sebaiknya dilakukan penelitian tentang pengaruh lama dan suhu pemanasan dalam pembuatan sirup buah naga merah.

\section{DAFTAR PUSTAKA}

[1] Apandi. M. 1984. Teknologi Buah dan Sayur. Alumni Bandung. Bandung

[2] Buckle dkk, Edwards, G. H. Fleet dan M. Wootton, 1989. Ilmu pangan. UI press. Jakarta.

[3] Dewan Standarisasi Nasional.1998.SNI 01-35441994: Sirup. Departemen Perindustrian. Jakarta

[4] Hanifiah, 2002..rancangan percobaan teori dan aplikasi fakultas pertanian universitas sriwijaya. Palembang

[5] Hadiwijaya, H.'Lukma, dan Aisman,2013pengaruh Perbedaan Penambahan Gula Terhadap KarakteristikSirupBuah Naga Merah (Hylocereus polyrhizus)

[6] Kristanto, D. 2003. Buah Naga Pembudidayaan di Pot dan di Kebun. Penebar Swadaya. Jakarta.

[7] Lim, Y.Y., Lim, T.T., Tee, J.J. 2006.Antioxidant properties of several tropical fruits; a comparative study. Journal of food chemistry.Monash University

[8] Marhazlina (2008), peneliti Department of Nutrition andDietetics Faculty of Medicineand Health Sciences UniversitiPutra Malaysia

[9] Mizrahi, Y., J. Moyal, A. Nerd and Y. Sitrit.2002.Metaxenia in the vive cacti.Cambridge University: Cambridge.

[10] Mizrahi, Y., E. Raveh, E. Yossov, A. Nerd and J. Ben-Asher, 2002.New Fruit Crops WithHigh Water Use Efficiency. In: Issues innew crops and new uses. J. Janick and A.Whipkey (eds.). ASHA Press, Alexandria,VA. P 216 - 222.

[11] Nasution, Z., Bakkara, T. dan Manulu M. 2006. Pemanfaatan Wortel (Daucus carota) dalam Pembuatan Mie Basah serta Analisa Mutu Fisik 
Jurnal AGROTEK Vol. 5 No.2, 2018 / Kajian Persentase Penambahan Gula Terhadap Komponen Mutu Sirup Buah Naga Merah/ Asmawati , Hamzan Sunardi , Syirril Ihromi.

dan Mutu Gizinya. Jurnal Ilmiah PANNMED.

Vol.1. No.1. Juli. 2006. Hal 9-13.

[12] Raveh, E., Nerd, A.And Mizrahi, Y. 1998. Responses of Two Hemi Epiphytic Fruit Crop Cacti to Different Degrees of shde. Scientia Holticultura, 73:

[13]Rosenau, M.J., The Milk Question, Haughton Mifflin Company, Boston, 1913

[14] Saati, Elfi Anis. 2009. IdentifikasiDan Uji Kualitas PigmenKulit Buah Naga Merah(Hylocareus costaricensis)Pada Beberapa UmurSimpan Dengan PerbedaanJenis Pelarut. Direktorat Penelitian dan Pengabdian Masyarakat. JIPTUMMDPPM.UMM. Malang

[15] Satuhu, S. 1994. Penanganan dan Pengolahan Buah.PT Penebar Swadaya. Jakarta.

[16] Soekarto, S.T. 1985. Penilaian Organoleptik Untuk Industri Pangan dan Hasil Pertanian.PT. Bhratana Karya Aksara. Jakarta.).

[17] Sudarmadji, S., B. Haryono dan Suhardi. 1996. Prosedur Analisa Bahan Makanan Dan Pertanian. Liberty. Yogyakarta.

[18] Sutomo, Budi. 2007. Buah NagaMerah - Segar danBerkhasiat. http://myhobbyblogs.com

[19]Wu, L.C., Hsu, H.W., Chen, Y.C., Chiu, C.C., Lin, Y.I. \& Ho, J.A. 2006. Antioxidant and Antiproliferative Activities of Red Pitaya. Food

[20]Winarno. FG. 1989. Kimia Pangan dan Gizi. Penerbit PT Gramedia Pustaka Utama. Jakarta.

[21]Winarno FG.2002. Kimia Pangan dan Gizi.PT Gramedia Pustaka Utama.jakarta

[22]Winarno,F.G. 2004. Kimia Pangan dan gizi.Gramedia Pustaka Utama,Jakarta.

[23] Zainoldin, K.H., Baba, A.S.2009. The Effect of Hylocereus polyrhizus and Hylocereus undatus on Physicochemical, Proteolysis, and Antioxidant Activity in Yogurt.World Academy of Science, Enginering and Technology 60. 